\title{
TAGLINE "ADA AQUA" EFFECTIVENESS USING EPIC MODEL IN KELURAHAN RANGKAPAN JAYA BARU PANCORAN MAS DEPOK
}

\author{
Ade Purwanto ${ }^{1}$, Khoirul Umam ${ }^{2 *}$ \\ ${ }^{1}$ Alumny of Indraprasta PGRI University \\ ${ }^{2}$ Indraprasta University PGRI, Faculty of Education and Social Knowledge \\ TB. Simatupang, Jl. Nangka Raya No.58 C, Jagakarsa, Jakarta 12530 \\ * Penulis korespondensi; Email: khoirul.elmariachi@gmail.com
}

\begin{abstract}
One measure of the success of advertising is its ability to create perspective space in the minds of audiences and consumers. Advertising as a message delivery tool does not only function to provide information, is persuasive and reminds audiences, but must also have an impact on consumers in the form of purchasing actions and attitudes towards products as expected by producers. This study aims to analyze the impact of AQUA product advertisements with the tagline "Ada AQUA" to consumers by using the EPIC model (Emphaty, Persuation, Impact, Communication). The research method used is quantitative descriptive. The results showed that AQUA ads with the tagline "Ada AQUA" were in the effective category as evidenced by the results of Emphaty dimensions of 4.15, which meant consumers liked and were interested in AQUA ads, Persuation dimensions of 3.89 showed AQUA ads were able to strengthen their image and character in the minds of consumers, the Impact dimension of 3.93 shows consumers more easily recognize AQUA ads with that tagline and Communcations dimensions of 4.06 indicate consumers are able to remember AQUA ads well. Broadly speaking, the conclusions obtained are AQUA ads with the tagline "Ada AQUA" effective in delivering the message to the target audience (consumers).
\end{abstract}

Keywords: Advertising; empathy; persuasion; impact; communication.

\section{INTRODUCTION}

Advertisements almost every day hit people's lives and mindsets. The language of advertising is able to reconstruct messages that are able to reach the audience so that it becomes a thought and change in consumer behavior.

Today consumers are more educated and knowledgeable. They have the means to verify company claims and look for superior alternatives. In the context of advertising, companies must be able to create effective and meaningful advertising messages, especially in determining the tagline (slogan) that is deep in consumer memory. PT. Aqua Golden Mississippi Tbk, as one of the largest bottled water companies in Indonesia, has been able to create a brand perspective for its customers well. This is of course supported by the ability of the company to create and build its advertising messages well and effectively and be able to instill the brand image in the minds of consumers well, including in creating effective and strong taglines that can be firmly planted in the minds of consumers. Based on the data, within 3 consecutive years (2015-2017) the AQUA brand has been able to place and maintain its position as number one when compared to other competing brands, as shown in Table 1

Some AQUA advertisements that have appeared, use a tagline such as "SemuaBerawaldari Kita", "Kebaikan Alam KebaikanHidup", "Gagal Fokus" and "Ada AQUA". Each tagline gives consumers different meanings and perspectives. An interesting point to examine from these taglines is how much the tagline effectiveness of AQUA ads is to build consumer interest (emphaty), the strength of the brand character in the minds of consumers (persuasive), consumer involvement in the brand (impact), and memory (memories) left by these advertising messages deeply in (communications) consumer memory.

Table 1. Top Brand Index of Bottled Water in Indonesia

\begin{tabular}{lccc}
\hline \multirow{2}{*}{ BRANDS } & \multicolumn{3}{c}{ TOP BRAND INDEX } \\
\cline { 2 - 4 } & $\mathbf{2 0 1 5}$ & $\mathbf{2 0 1 6}$ & $\mathbf{2 0 1 7}$ \\
\hline AQUA & $75.9 \%$ & $73.4 \%$ & $73.3 \%$ \\
VIT & $5.0 \%$ & $5.5 \%$ & $6.1 \%$ \\
Club & $2.6 \%$ & $3.4 \%$ & $4.5 \%$ \\
Ades & $2.6 \%$ & $3.4 \%$ & $4.1 \%$ \\
Cleo & & $2.0 \%$ & \\
\hline
\end{tabular}

Source: www.topbrand-award.com.

In this study, the researcher took one of the taglines, namely "Ada AQUA" to measure how much impact the tagline has in shaping the perspective and attitudes of consumers towards AQUA. So that this research can also be formulated that "Is the tagline" There is AQUA "as a whole effective if viewed from the aspects of Emphaty, Persuasive, Impact and Communication?"

Ads are translated and understood as a form of communication that uses paid media. The message in the advertisement is deliberately formed and designed in such a way as to influence the target audience to act and behave according to the wishes of the advertiser in the present or future time, as stated by. 
Understanding advertising, Machfoedz (2010: 139-141) says that, advertising is all forms of presentation of information and promotions directly carried out by sponsors to offer ideas, goods or services. Advertising has a non-personal nature and is a tool to promote products and services without holding direct contact and advertisers must pay a certain applicable rate.Subagyo (2010: 136) argues that, "advertising is a promotion or non-individual service carried out by a sponsor or certain individual company that can be identified and who pays communication."From the two definitions above, it can be concluded that advertising is a form of mass communication such as newspaper radio, magazines and so on.

According to Kotler and Keller (2012: 490-491) advertising has three advantages including:1) Pervasivenes: marketers can repeat the same message through advertisements. With advertising, buyers can receive and compare messages from various competing companies. Large-scale advertising will create a positive message about size, strength, and success (the sales company), 2) Amplied Expressiveness: advertising provides an opportunity to dramatize the company and its products through the use of prints, sounds, and colors, 3) Control: advertisers can determine aspects of the brand and product that will be focused to be communicated.

What factors make the ad effective? Before answering the question, we need to understand the word "effective" in an advertisement itself. At least, Nielsen (Nielsen Ads@work, 2008) (Brands, 2008) provides four indicators to determine the effectiveness of an advertisement for its audience. First, advertising must be able to change audience behavior (change behavior). In this case, the target of advertising is to be able to make consumers or audiences persuaded to try the products offered by the company. Second, advertising must be able to educate consumers about the products offered. On the other hand, advertising must also be able to make consumers always remember the product offered (educate or remind). So, the company must be able to make communication and interactive dialogues well and willingly must be able to instill memory of the product deeply in the minds of consumers so that consumers are only able to remember these products compared to other products. Third, advertising must be able to evoke the emotional side of consumers (evoke an emotional response). Meaning that the target of advertising is to make the memories of consumers or audiences always connected with the brand in all things, situations and conditions (improve brand affinity or association). Fourth, advertising must be able to make the brand recognized in the midst of society. For that, advertising must be able to make the brand image stand out from other brands (standt out from others).
The results of research on the effectiveness of advertising on consumer behavior states that creative advertising is able to change consumer behavior to prefer the ad, the brand of its product and the intensity of its behavior (Baack, Wilson, van Dessel, \& Patti, 2016). Another study on the behavior of outdoor advertising stated that the effectiveness of advertising was influenced by positive and negative attitudes from both the message and the procedures for delivering the ad itself and the audience exposed to the advertisement. For audiences who are positive about advertising, they are better able to remember advertisements than negative audiences (Donthu, Cherian, and Bhargava, 1993) in (Mehta, 2000). While the study of the impact of advertising in general, which is viewed from the "involvement" of the audience on advertising, explains that the effectiveness of advertising can be measured by the time spent by the audience and their involvement in seeing print ads. Some audiences who think that advertising has good benefits and are used as a learning tool, they spend more time looking at advertisements and are more deeply involved in these ads. While for those who feel that advertising is quite disturbing and does not provide any benefits, they often feel annoyed and do not want to be involved in the advert (james and cover: 1992) in (Mehta, 2000).

Meanwhile, a study of the effectiveness of advertising on media that is associated with age from the audience explained that online media is the most effective advertising tool to influence buying behavior among youth, while print media will increase the credibility of the ad itself. in this context, advertisers are required to be able to use both types of media and always explore all the potential that exists in online media (Vinaya \& S. Mehtora, 2018).

According to Belch (2012: 301), the attractiveness of advertisements is divided into two, includeing the following:1) Rational Attraction Informal rational appeal, focusing on the practical, functional or utilitarian needs of the target audience, emphasizes features, benefits and reasons for owning or using a particular brand of product or service.2) Emotional Attractiveness Emotional attractiveness relates to social needs and/or psychic target audience. Advertisers use emotional attraction with the aim that the positive feelings of the target audience can be transferred to the brand and to influence the interpretation of the target audience from the experience of using a particular product or service.

The effectiveness of advertising According to Durianto (2003: 15), can be measured using several models including:1) Consumer Decision Model $(\mathrm{CDM})$, which is a model with six interrelated varia- 
bles, namely advertising messages, brand recognition, consumer trust, consumer attitudes, real purchase and purchase intentions. 2) Direct Rating Method (DRM), this method is used to evaluate the strength of an ad that is related to the ability of ads to get attention, whether or not the ad is read carefully, whether or not the ad is understood, the ability of the ad to arouse feelings and the ability of advertisements to affect behavior. 3) Customer Response Index (CRI), which is the result of multiplication of awareness, understanding, interest, intention to buy and act to buy.4) Emphaty, Persuation, Impact and Communication (EPIC), a model developed by AC Nielsen with four dimensions, namely empathy, persuasion, impact and communication.

The effectiveness of advertising can be measured using EPIC Model in (Durianto\&Dkk, 2003) EPIC Model from AC Nielsen one of the leading marketing research companies in the world includes four critical dimensions, namely: empathy, persuasion, impact and communication (Empathy, Persuasion, Impact and Communications) with the following explanation: Dimensions of Empathy. The Empathy dimension provides valuable information about the attractiveness of a brand. Emphaty is a state of mentality that makes someone identify himself or feel himself in a state of feeling or thought that is the same as another person or group. Emphaty involves consumer affection and cognition, according to J. Paul Peter and Jerry C Olson (2013: 21) affection and consumer cognition refers to the two types of mental responses that consumers show to the stimulus and events around them. Affection (affect) refers to the things they feel about stimulus and events, for example whether they like or not a product. Cognition refers to the things they think like trust in a product.

Persuasion. The persuasion dimension informs what can be given an advertisement to increase or strengthen the character of a brand, so that ad marketing gets an understanding of the impact of advertising on consumers' desire to buy and obtain the ability of an advertisement to develop the attractiveness of a brand. In the advertising world, persuasion is a change in belief, attitude, and desire to behave due to one promotional communication.

Impact. The impact dimension shows whether a brand can stand out compared to other brands in a similar category and whether an advertisement can engage consumers in the message delivered.

Communication.The communication dimension provides information about the ability of consumers to remember the main message delivered, consumer understanding, and the strength of the impression left by the message.
Framework of thinking;

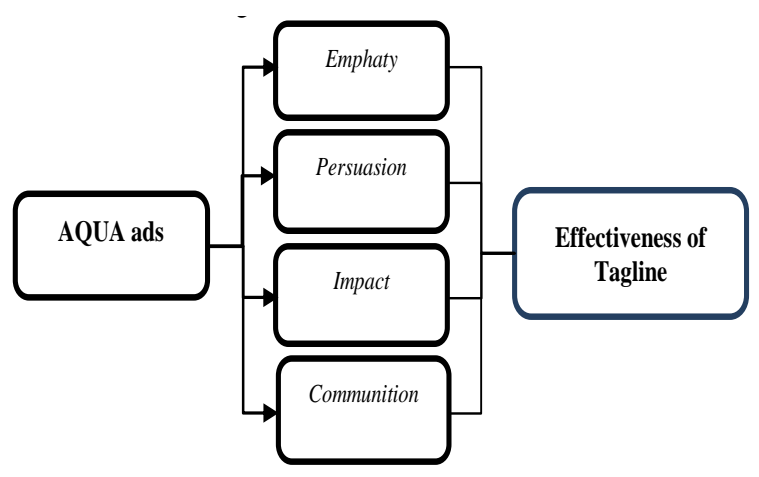

Figure 1. Thinking Framework

The basis of the preparation of this research framework is beginning with the idea that marketing communication can be expressed as a promotional activity that aims to convey the message to consumers by using various media, one of them is advertising. products, advertisements are also seen as entertainment media and marketing communication media that are effective enough to reach target markets, especially if they are aired on will get attention and are always remembered.

Based on the presentation of the material and the framework above, a hypothesis is taken, namely "AQUA Ads with the tagline" There is AQUA "which is effective in terms of the dimensions of empathy, persuasion, impact and communication."

\section{Purpose}

The purpose of this research is to Assess the effectiveness of AQUA product advertisements from PT. Aqua Golden Mississippi Tbk. With the tagline "Ada AQUA" which broadcast on television.

\section{RESEARCH METHODOLOGY}

This type of research is quantitative descriptive with survey techniques. According to Sugiyono (2012: 12) Survey method is used to get data from certain natural places (not artificial), but researchers treat them in data collection, for example distributing questionnaires, tests, structured interviews and so on (Sugiyono, 2012: 12).

The population of this study is consumers or respondents who live in the area of Rangkap Jaya Baru Village, and research was also conducted at the Rangkap Jaya Baru Sub-District office, Pancoran Mas Sub-District, Depok City 16434. The population in this study was 8,689 heads of households.

According to Sugiyono (2015: 61) Samples are part of the number and characteristics possessed by the population. If the population is large, and researchers are not likely to learn all that is in 
popolation, for example due to limited funds, energy and time, the researcher can use samples taken from that population. What is learned from the sample, the conclusions will be applied to the population. For that samples taken from the population must be truly representative (representing) (Sugiyono, 2015: 62). In this study the sample was determined using the Slovin approach. As explained earlier, the population is 8,689 heads of families, so the number of samples can be determined using the following formula:

$\mathrm{n}$ : Samples

$$
n=\frac{N}{1+N e^{2}}
$$

$\mathrm{N}$ : Population

$e$ : Errors that are tolerated, $10 \%$

So based on calculations, the sample size is 99 respondents.

The data used in this study are primary and secondary data. Primary data is obtained through interviews using questionnaires using a Likert scale to measure the effectiveness of the tagline "Ada AQUA" using the EPIC model, while secondary data is obtained through literature studies through the internet and relevant research results.

The data analysis technique that will be carried out in this study uses a quantitative approach, so we need a step-by-step technique to analyze the data that has been obtained. Data obtained in the study and analyzed so that it can provide a clear work system. The method used in analyzing is the EPIC Model method. This is because certain limits of qualitative analysis conducted by companies to assess the effectiveness of advertising have not been able to provide detailed information in describing a condition.EPIC Model is done to measure the effectiveness of advertising. EPIC Model consists of four dimensions, namely: Emphaty, Persuasion, Impact and Communication. From the answers to the questionnaire statements covering the four dimensions, the analysis will be used as follows:

\section{Simple Tabulation Analysis}

In simple tabulation analysis, the data obtained is processed in the form of percentages, with the following formula (Durianto, 2003: 78).

$$
P=\frac{f_{i}}{\sum f_{i}} x 100 \%
$$

$\mathrm{P}$ : the percentage of respondents who chose a particular category

$f i$ : the number of respondents who chose certain categories

$\sum f_{i}:$ number of respondents

\section{Average Score}

Each respondent's answer from the statement given to the consumer is then given a weight using the Likert scale which has been explained in the previous section. How to calculate the score is to add all the results of the value of each weight divided by the total frequency. With the formula as follows:

$\mathrm{X}$ : weighted average

$$
x=\frac{f i \times w i}{\sum f i}
$$

$f_{i}:$ frequency

$w_{i}$ : weight

After calculating the average score, the next step uses a range of rating scales to determine the position of respondents' responses by using the score value of each variable. The alternative answer weight formed from the ranking scale technique consists of a range of 1 to 5 which describes a very negative position to a very positive position. Then the scale ranges are calculated using the following formula:

Dimana:

$$
R s=\frac{R_{(\text {bobot })}}{M}=\frac{5-1}{5}=0,8
$$

$\mathrm{R}_{\text {(weight }}$ : The biggest weight - the smallest weight

M : Number of weight categories

So that the decision position becomes:

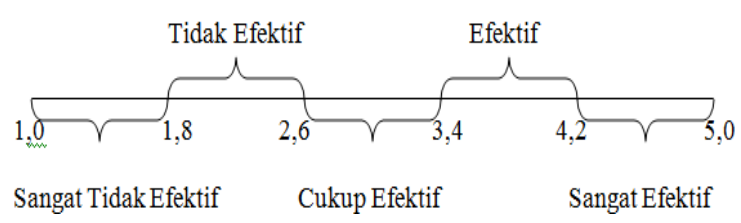

Source: Durianto (2003:95)

Figure 2. Range of EPIC Model Scale

\section{Determine the EPIC Rate Formula}

The next step is to determine the EPIC rate formula, the result of the EPIC Rate will describe the promotion position of a product in the respondents' perceptions, according to the range of scales that have been determined above with the following formula:

$=\frac{\text { EPICrate }}{\text { Empathy }+ \text { Persuasion }+ \text { Impact }+ \text { Communication }}$

After the required data is collected, the next step is the data analysis stage. In this stage the researcher analyzes the data that has been processed so that conclusions and analysis of the research can be obtained. 


\section{RESULTS AND DISCUSSION}

\section{Empathy}

The empathy dimension statement is intended to find out whether consumers like an advertisement and describe how consumers see the relationship between an ad and their personal.

\section{Results of Calculation of Empathic Dimensions}

Empathy is a dimension that involves a person's interest through two aspects, namely affection (feeling) and cognition (thinking) of a product after seeing the ad that is displayed on a media. This is evidenced by changes in the minds of consumers to purchase these products. Based on Table 4, it is known that the average score of empathy dimensions is 4.15. The score is then included in the EPIC Model scale range. The results of AQUA ad preference measurements are declared effective. This informs that consumers like and are interested in AQUA ads with the tagline "Ada AQUA".

Table 2. Calculation of the Dimensions of Empathy Factors

\begin{tabular}{ccccccc}
\hline $\begin{array}{c}\text { Attribute } \\
\begin{array}{c}\text { State- } \\
\text { ment }\end{array}\end{array}$ & $\begin{array}{c}\text { Strong- } \\
\text { ly } \\
\text { agree }\end{array}$ & \multicolumn{4}{c}{ Tgtal } \\
AgreeDoubtfulDisagree & $\begin{array}{c}\text { Strongly Total } \\
\text { disagree }\end{array}$ \\
\hline 1 & 34 & 64 & 1 & 0 & 0 & 99 \\
2 & 32 & 55 & 10 & 2 & 0 & 99 \\
3 & 37 & 49 & 9 & 4 & 0 & 99 \\
4 & 50 & 43 & 3 & 3 & 0 & 99 \\
5 & 24 & 60 & 14 & 1 & 0 & 99 \\
6 & 6 & 65 & 19 & 7 & 2 & 99 \\
\hline
\end{tabular}

Source: Primary data processed in May, 2018

a. The results of simple data tabulation analysis of Empathy dimensions

Table 3. Simple Dimensions of Empathy Data Tabulation Analysis

\begin{tabular}{|c|c|c|c|c|c|c|}
\hline \multirow[b]{2}{*}{$\begin{array}{c}\text { Attribute } \\
\text { State- } \\
\text { ment }\end{array}$} & \multicolumn{5}{|c|}{ Simple Tabulation Analysis } & \multirow[b]{2}{*}{$\begin{array}{c}\text { Total } \\
(\%)\end{array}$} \\
\hline & $\begin{array}{c}\text { Strong- } \\
\text { ly } \\
\text { agree }\end{array}$ & Agree & $\begin{array}{c}\text { Doubt- } \\
\text { ful }\end{array}$ & $\begin{array}{l}\text { Disa- } \\
\text { gree }\end{array}$ & $\begin{array}{l}\text { Strong- } \\
\text { ly } \\
\text { Disa- } \\
\text { gree }\end{array}$ & \\
\hline 1 & $34 \%$ & $65 \%$ & $1 \%$ & $0 \%$ & $0 \%$ & $100 \%$ \\
\hline 2 & $32 \%$ & $56 \%$ & $10 \%$ & $2 \%$ & $0 \%$ & $100 \%$ \\
\hline 3 & $37 \%$ & $49 \%$ & $9 \%$ & $4 \%$ & $0 \%$ & $100 \%$ \\
\hline 4 & $51 \%$ & $43 \%$ & $3 \%$ & $3 \%$ & $0 \%$ & $100 \%$ \\
\hline 5 & $24 \%$ & $61 \%$ & $14 \%$ & $1 \%$ & $0 \%$ & $100 \%$ \\
\hline 6 & $6 \%$ & $66 \%$ & $19 \%$ & $7 \%$ & $2 \%$ & $100 \%$ \\
\hline
\end{tabular}

b. Total mean score of Empathy

Table 4. Average Empathy Dimension Score

\begin{tabular}{cccc}
\hline $\begin{array}{c}\text { Attribute } \\
\text { Statement }\end{array}$ & $\begin{array}{c}\text { Frequency } \\
\text { X Weight }\end{array}$ & $\begin{array}{c}\text { Average Score } \\
\text { per Attribute }\end{array}$ & Total \\
\hline 1 & 429 & 4,33 & \\
2 & 414 & 4,18 & \\
3 & 416 & 4,20 & $\mathbf{4 , 1 5}$ \\
4 & 437 & 4,41 & \\
5 & 404 & 4,08 & \\
6 & 363 & 3,67 & \\
\hline \multicolumn{5}{c}{ Total } & $\mathbf{2 4 , 8 8}$ \\
\hline
\end{tabular}

Sumber: Data primer diolah Mei, 2018

\section{Persuasion}

The dimension of persuasion statement informs what is given by an advertisement to improve or strengthen the character of a brand.

a. The results of the persuasion dimension calculation

Table 5. Calculation of the Persuasion Dimension Factor

\begin{tabular}{ccccccc}
\hline $\begin{array}{c}\text { Attribute } \\
\begin{array}{c}\text { State- } \\
\text { ment }\end{array}\end{array}$ & $\begin{array}{c}\text { Strong- } \\
\text { ly } \\
\text { agree }\end{array}$ & \multicolumn{4}{c}{ Total } \\
AgreeDoubtfulDisagree & & \multicolumn{4}{c}{$\begin{array}{c}\text { Strongly Total } \\
\text { disagree }\end{array}$} \\
\hline 7 & 29 & 52 & 12 & 6 & 0 & 99 \\
8 & 13 & 52 & 25 & 6 & 3 & 99 \\
9 & 15 & 59 & 17 & 8 & 0 & 99 \\
10 & 12 & 55 & 20 & 8 & 4 & 99 \\
11 & 26 & 57 & 14 & 2 & 0 & 99 \\
12 & 29 & 54 & 13 & 2 & 1 & 99 \\
\hline
\end{tabular}

Source: Primary data processed in May, 2018

b. The results of simple data tabulation analysis are persuasion dimensions

Tabel 6. Simple Persuasion Dimension Data Analysis

\begin{tabular}{ccccccc}
\hline $\begin{array}{c}\text { Attribute } \\
\text { State- } \\
\text { ment }\end{array}$ & $\begin{array}{c}\text { Simple Tabulation Analysis } \\
\text { Strongly } \\
\text { agree }\end{array}$ & $\begin{array}{c}\text { Agree } \\
\text { Doubt- } \\
\text { ful }\end{array}$ & $\begin{array}{c}\text { Strongly } \\
\text { Total } \\
\text { disagree }\end{array}$ \\
\hline 5 & $29 \%$ & $53 \%$ & $12 \%$ & $6 \%$ & $0 \%$ & $100 \%$ \\
6 & $13 \%$ & $53 \%$ & $25 \%$ & $6 \%$ & $3 \%$ & $100 \%$ \\
7 & $15 \%$ & $60 \%$ & $17 \%$ & $8 \%$ & $0 \%$ & $100 \%$ \\
8 & $12 \%$ & $56 \%$ & $20 \%$ & $8 \%$ & $4 \%$ & $100 \%$ \\
9 & $26 \%$ & $58 \%$ & $14 \%$ & $2 \%$ & $0 \%$ & $100 \%$ \\
10 & $29 \%$ & $55 \%$ & $13 \%$ & $2 \%$ & $1 \%$ & $100 \%$ \\
\hline
\end{tabular}

Source: Primary data processed in May, 2018

c. The total score of the average dimension of persuasion

Table 7. Average Persuasion Dimension Score

\begin{tabular}{|c|c|c|c|}
\hline $\begin{array}{c}\text { Attribute } \\
\text { Statement }\end{array}$ & $\begin{array}{l}\text { Frequency } \\
\text { X Weight }\end{array}$ & $\begin{array}{l}\text { Average Score } \\
\text { per Attribute }\end{array}$ & Total \\
\hline 7 & 401 & 4,05 & \multirow{6}{*}{3,89} \\
\hline 8 & 363 & 3.67 & \\
\hline 9 & 378 & 3.82 & \\
\hline 10 & 360 & 3,64 & \\
\hline 11 & 404 & 4,08 & \\
\hline 12 & 405 & 4,09 & \\
\hline & & 23,34 & \\
\hline
\end{tabular}

Sumber: Data primer diolah Juli, 2018. 
Persuasion is a dimension that involves strengthening the character of a product displayed in advertisements compared to other similar products. In the persuasion dimension, the AQUA brand is more remembered by consumers than other similar products. This can be proven based on Table 7, it is known that the average score of the persuasion dimension is 3.89. The score is then included in the EPIC Model scale range. The results of the measurement of the effectiveness of the advertising preferences are in the range of effective scale, informing that through AQUA product advertisements with the tagline "Ada AQUA" can provide improvement and strengthening of AQUA brand characters compared to similar brands to consumers.

\section{Impact}

The impact dimension statement is intended so that the impact used from the advertising results is the amount of product knowledge that consumers achieve through the level of consumer involvement with the product or the selection process.

a. The results of the Impact dimension calculation

Table 8. Calculation of IMPACT Dimension Factors

\begin{tabular}{ccccccc}
\hline $\begin{array}{c}\text { Attribute } \\
\text { State- } \\
\text { ment }\end{array}$ & $\begin{array}{c}\text { Strongly } \\
\text { agree }\end{array}$ & $\begin{array}{c}\text { Agree } \\
\text { Doubt- } \\
\text { ful }\end{array}$ & Disagree & $\begin{array}{c}\text { Strongly Total } \\
\text { disagree }\end{array}$ \\
\hline 13 & 19 & 65 & 14 & 1 & 0 & 99 \\
14 & 17 & 60 & 15 & 7 & 0 & 99 \\
15 & 25 & 62 & 11 & 1 & 0 & 99 \\
16 & 33 & 50 & 14 & 2 & 0 & 99 \\
17 & 14 & 63 & 18 & 4 & 0 & 99 \\
18 & 5 & 61 & 18 & 11 & 4 & 99 \\
\hline
\end{tabular}

Source: Primary data processed in May, 2018

b. The results of simple data tabulation analysis on the IMPACT dimension

Table 9. Simple Data Dimension Analysis of IMPACT Dimensions

\begin{tabular}{ccccccc}
\hline $\begin{array}{c}\text { Attribute } \\
\begin{array}{c}\text { State- } \\
\text { ment }\end{array}\end{array}$ & $\begin{array}{c}\text { Strongly } \\
\text { agree }\end{array}$ & $\begin{array}{c}\text { Sgree } \\
\text { Agoubulation Analysis }\end{array}$ & $\begin{array}{c}\text { Doubt- } \\
\text { ful }\end{array}$ & $\begin{array}{c}\text { Disa- Strongly } \\
\text { gree }\end{array}$ & $\begin{array}{c}\text { Total } \\
\text { disagree }\end{array}$ \\
\hline 13 & $19 \%$ & $66 \%$ & $14 \%$ & $1 \%$ & $0 \%$ & $100 \%$ \\
14 & $17 \%$ & $61 \%$ & $15 \%$ & $7 \%$ & $0 \%$ & $100 \%$ \\
15 & $25 \%$ & $63 \%$ & $11 \%$ & $1 \%$ & $0 \%$ & $100 \%$ \\
16 & $33 \%$ & $51 \%$ & $14 \%$ & $2 \%$ & $0 \%$ & $100 \%$ \\
17 & $14 \%$ & $64 \%$ & $18 \%$ & $4 \%$ & $0 \%$ & $100 \%$ \\
18 & $5 \%$ & $62 \%$ & $18 \%$ & $11 \%$ & $4 \%$ & $100 \%$ \\
\hline
\end{tabular}

Source: Primary data processed in May, 2018

c. Total mean score of IMPACT dimensions

Table 10. IMPACT Dimension Average Score

\begin{tabular}{cccc}
\hline $\begin{array}{c}\text { Attribute } \\
\text { Statement }\end{array}$ & $\begin{array}{c}\text { Frequency } \\
\text { X Weight }\end{array}$ & $\begin{array}{c}\text { Average Score } \\
\text { per Attribute }\end{array}$ & Total \\
\hline 13 & 399 & 4,03 & \\
14 & 384 & 3,88 & \\
15 & 408 & 4,12 & \multirow{2}{*}{3,93} \\
16 & 411 & 4,15 & \\
17 & 384 & 3,88 & \\
18 & 399 & 3,53 & \\
\cline { 1 - 2 } Total & $\mathbf{2 3 , 5 9}$ & \\
\hline
\end{tabular}

Source: Primary data processed in May, 2018
Impact can be interpreted whether a brand can look more prominent than other brands in a similar category and whether an advertisement can engage consumers in the message delivered. Impact dimensions can be said to be good if consumers can feel the differences that exist such as the advantages of products advertised compared to other similar products. Based on Table 10, it is known that the average score of the impact dimension is 3.93. The score is then included in the EPIC Model scale range. The results of the measurement of the effectiveness of the advertisement are included in the effective scale range. This can be interpreted that the AQUA brand is superior and prominent compared to other brands.

\section{Communication}

The communication dimension statement is aimed at whether consumers understand what AQUA advertisements convey.

a. Results of calculation of communication dimensions

Table 11. Calculation of Communication Dimension Factors

\begin{tabular}{ccccccc}
\hline \multirow{2}{*}{$\begin{array}{c}\text { Attribute } \\
\text { Statement }\end{array}$} & \multicolumn{5}{c}{ Total } & \\
\cline { 2 - 6 } & $\begin{array}{c}\text { Strongly } \\
\text { agree }\end{array}$ & Agree & $\begin{array}{c}\text { Doubt- } \\
\text { ful }\end{array}$ & $\begin{array}{c}\text { Disa- } \\
\text { gree }\end{array}$ & $\begin{array}{c}\text { Strongly Total } \\
\text { disagree }\end{array}$ \\
\hline 19 & 23 & 52 & 16 & 7 & 1 & 99 \\
20 & 17 & 59 & 16 & 6 & 1 & 99 \\
21 & 24 & 65 & 7 & 3 & 0 & 99 \\
22 & 23 & 63 & 12 & 1 & 0 & 99 \\
23 & 26 & 61 & 10 & 2 & 0 & 99 \\
24 & 36 & 57 & 5 & 1 & 0 & 99 \\
\hline
\end{tabular}

Source: Primary data processed in May, 2018

b. The results of simple data tabulation analysis of communication dimensions

Table 12. Communication Dimension Data Tabulation Analysis

\begin{tabular}{ccccccc}
\hline \multirow{2}{*}{$\begin{array}{c}\text { Attribute } \\
\begin{array}{c}\text { State- } \\
\text { ment }\end{array}\end{array}$} & $\begin{array}{c}\text { Strong- } \\
\text { ly } \\
\text { agree }\end{array}$ & Agree & $\begin{array}{c}\text { Doubt- } \\
\text { ful }\end{array}$ & $\begin{array}{c}\text { Strong- } \\
\text { Disagree }\end{array}$ & $\begin{array}{c}\text { ly } \\
\text { Disa- } \\
\text { gree }\end{array}$ \\
\hline 19 & $23 \%$ & $53 \%$ & $16 \%$ & $7 \%$ & $1 \%$ & $100 \%$ \\
20 & $17 \%$ & $60 \%$ & $16 \%$ & $6 \%$ & $1 \%$ & $100 \%$ \\
21 & $24 \%$ & $66 \%$ & $7 \%$ & $3 \%$ & $0 \%$ & $100 \%$ \\
22 & $23 \%$ & $64 \%$ & $12 \%$ & $1 \%$ & $0 \%$ & $100 \%$ \\
23 & $26 \%$ & $62 \%$ & $10 \%$ & $2 \%$ & $0 \%$ & $100 \%$ \\
24 & $36 \%$ & $58 \%$ & $5 \%$ & $1 \%$ & $0 \%$ & $100 \%$ \\
\hline Source: Primary data processed in May, 2018 \\
\hline
\end{tabular}

c. Total score for average communication dimensions

Communication in advertising is where companies try to inform, persuade, and remind consumers directly or indirectly about the products and brands 
sold. Effective communication in advertising must be able to change the attitudes and behavior of individuals or the public exposed to the advertisement in the form of changes in behavior of the desire to buy products that are advertised and willing voluntarily with their own desire to indirectly market the product to other individuals. Based on Table 13, it is known that the mean score of the Communication dimension is 4.06. The score is then included in the EPIC Model scale range. The results of the measurement of the effectiveness of the advertisement are included in the effective scale range. This shows that the AQUA advertising message with the tagline "Ada AQUA" through the media is communicative. This is evidenced by the attitude of consumers who can remember the tagline "Ada AQUA" well.

Table 13. Communication Dimension Average Score

\begin{tabular}{cccc}
\hline $\begin{array}{c}\text { Attribute } \\
\text { Statement }\end{array}$ & $\begin{array}{c}\text { Frequency } \\
\text { X Weight }\end{array}$ & $\begin{array}{c}\text { Average Score } \\
\text { per Attribute }\end{array}$ & Total \\
\cline { 1 - 3 } 10 & 386 & 3,90 & \\
20 & 382 & 3,86 & \\
21 & 407 & 4,11 & \multirow{4}{4}{, 06} \\
22 & 405 & 4,09 & \\
23 & 408 & 4,12 & \\
24 & 425 & 4,29 & \\
\cline { 1 - 2 } Total & $\mathbf{2 4 , 3 7}$ & \\
\hline
\end{tabular}

Source: Primary data processed in May, 2018

The next step is to calculate the EPIC Rates as a whole as follows:

$$
\begin{gathered}
E P I C_{\text {rate }}= \\
\frac{\text { Empaty }+ \text { Persuasion }+ \text { Impact }+ \text { Communication }}{4} \\
E P I C_{\text {rate }}=\frac{4,15+3,89+3,93+4,06}{4}=4,01
\end{gathered}
$$

Overall the EPIC Rate is 4.01. This value can be interpreted that AQUA ads with the tagline "Ada AQUA" fall into the category of effective advertising.This can be interpreted that the audience can remember the main message delivered.

\section{CONCLUSION}

The results of measuring the effectiveness of advertisements with EPIC Model show that AQUA ads with the tagline "Ada AQUA" fall into the effective category (EPIC Rate worth 4.01). The explanation of the results of measuring the level of advertising effectiveness for each dimension is as follows:

a. The empathy dimension is in the range of effective scales with a value of 4.15 . This informs that consumers like and are interested in AQUA ads with the tagline "Ada AQUA"

b. The persuasion dimension is in the range of effective scale with a value of 3.89 . This informs that consumers can provide improvement and strengthening of the AQUA brand character.

c. The impact dimension is in the range of effective scale with a value of 3.93. This can be interpreted that the AQUA brand with the tagline "Ada AQUA" is more prominent than other similar brands.

d. Communication dimensions are in the range of effective scales with a value of 4.06 . This can be interpreted that the audience can remember the main message conveyed in AQUA ads with the tagline "Ada AQUA".

\section{REFERENCES}

Baack, D. W., Wilson, R. T., van Dessel, M. M., \& Patti, C. H. (2016). Advertising to businesses: Does creativity matter? Industrial Marketing Management, 55, 169-177. https://doi.org/10. 1016/J.INDMARMAN.2015.10.001

Belch, G. (2012). Advertising and Promotion An integrated Marketing Communication, 9th Edition. New York: Mc Graw HillInternational Edition.

Brands, W. (2008). ads @ work Nielsen. Retrieved from https://www.nielsen.com/content/dam/nielsen/en_us/documents/pdf/Fact Sheets/Nielsen ads@work brochure.pdf

Durianto, D., \& Dkk. (2003). Invasi Pasar Dengan Iklan Yang Efektif. Jakarta: Gramedia.

Kotler, P., \& Amstrong, G. (2012). Prinsip-Prinsip Pemasaran. Edisi 13. Jakarta: Erlangga.

Machfoed, M. (2010). Marketing Management Modern. Yogyakarta: Cakra Ilmu.

Mehta, A. (2000). Advertising Attitudes and Advertising Effectiveness. Journal of Advertising Research, 4O(3), 67-72. https://doi.org/10.2501/JAR40-3-67-72

Subagyo, A. (2010). Marketing in Business. Jakarta: Mitra WacanaMedia.

Sugiyono. (2012). Statistika Untuk Penelitian. Bandung: Alfa Beta.

Sugiyono. (2015). Metode Penelitan Kuantitatif, Киаlitatif, dan R\&D. Bandung: Alfa Beta.

Nielsen Ads@work. (2008). (Nielsen, Produser, \& Nielsen) Dipetik 05 12, 2019, dari www.nielsen. com: https://www.nielsen.com/content/dam/ nielsen/en_us/documents/pdf/Fact\%20Sheets/Ni elsen\%20ads@work\%20brochure.pdf

Vinaya, K. C., \& S. Mehtora. (2018). Print vs. Online Advertising: Impact on Buying Behavior of Youth - ProQuest. Global Media Journal, 16(31), 1. Retrieved from https://search.proquest.com/docview/2162427635/abstract/2F07F $2 \mathrm{~F} 3515 \mathrm{~F} 43 \mathrm{D} 9 \mathrm{PQ} / 1$ ?accountid $=38628$

www.topbrand-award.com 